\title{
EFFECTIVENESS OF PER-ORAL INSULIN IN HUMAN DIABETES
}

\author{
By J. R. MURLIN, C. B. F. GIBBS, M. J. ROMANSKY, T. B. STEINHAUSEN, \\ AND F. L. TRUAX \\ (From the Departments of Vital Economics and Medicine, University of Rochester School of \\ Medicine, Rochester)
}

(Received for publication May 2, 1940)

In previous reports one of us (M) and his associates $(1,2)$ have shown that hexylresorcinol aids in the absorption of insulin from the gastrointestinal tract of dogs. It has since been shown that other derivatives, the octyl and heptyl resorcinols (3) and the pentyl, butyl, and propyl resorcinols likewise are active in this physiologic process; the last two, however, less so than the higher compounds. Ethyl resorcinol proved completely inactive, as have the acyl resorcinols and the butyl ester of $\beta$-resorcinol (4). Reports on the effects of other substances found to retard digestion of insulin will be made in later papers.

None of the resorcinols having proved superior to the hexyl compound, it was decided to try this one on a series of diabetic patients. ${ }^{1}$

At the time of the report before the National Academy of Sciences (5) in Rochester (October 1937), it was stated that, "Trials with human subjects (normals) permit us at the present time only to state with certainty that, under the conditions defined, insulin can be absorbed in sufficient amount to produce abrupt changes in blood sugar. With some subjects we have thus far not been able to demonstrate any absorption and, under certain conditions not yet understood, persons who have previously given good absorption fail to do so. It is impossible to say at the present time how useful or important these observations may become in the treatment of diabetes."

With this statement plainly before him, a certain reporter sent to the Associated Press a dispatch completely at variance with the above, and the erroneous report was widely copied in the lay press. The story grew to the point where "Time" reported "a perfected compound of insulin and hexylresorcinol which may be swallowed as a tablet." Not a word was said about tablets either in the paper read before the Academy, the abstract published in Science, or in the statement given to the press along with statements from other speakers.

Trials of the absorption mixture which had

1 This investigation has been aided by a grant from the Insulin Committee of the University of Toronto, contributed by the manufacturers of insulin in the U. S. A. proved most effective in animal experiments were begun with diabetic patients in October, 1937 and were continued without interruption until June, 1938. They were resumed in December, 1938 and continued until July, 1939. Twenty patients were given the oral insulin over periods varying from two weeks to three and a half months. The results are reported in summary with some details on patients who showed greatest responses. It was not anticipated from the experience gained with dogs that it would be possible to replace all subcutaneous insulin in any other than the mildest cases requiring insulin. The report should not be regarded as anything more than a physiologic study of absorption of insulin from the alimentary tract of patients who have an interest in the outcome. Its value from the standpoint of treatment should be appraised in several other clinics where dietary and other factors can be controlled rigidly before there can be any hope of general usage by the medical profession. Improvement of absorption by other adjuvant substances has been obtained recently in the animal laboratory, but the point of safe application to the diabetic patient has not yet been reached.

Of the twenty patients selected from the outpatient diabetic clinic or the in-patients of Strong Memorial, Municipal, and General Hospitals in Rochester, two were studied in a preliminary way without an adequately controlled diet, four proved uncooperative, two became sugar free without insulin, one was quite old (68) and gave very little response to oral insulin, and one of the two who thought they had to have protamine insulin was very difficult to regulate to a satisfactory base level of sugar excretion or fasting blood sugar. Of the twenty only twelve gave good evidence of absorption under conditions which cannot be impeached.

These conditions included: (1) a period of adjustment of subcutaneous insulin to a point where both change of sugar excretion and change of blood sugar could be reliably measured; (2) per- 
TABLE I

Total digestibility not affected by oral insulin + hexylresorcinol and buffer (Subject T. L.)

\begin{tabular}{|c|c|c|c|c|c|c|c|}
\hline \multirow{2}{*}{$\begin{array}{l}\text { Date } \\
1938\end{array}$} & Period & & \multirow{2}{*}{$\mathbf{N}$} & \multirow{2}{*}{ Protein } & \multirow{2}{*}{ Fat } & \multirow{2}{*}{$\begin{array}{l}\text { Carbo- } \\
\text { hydrate }\end{array}$} & \multirow{2}{*}{ Ash } \\
\hline & Number & & & & & & \\
\hline \multirow[t]{2}{*}{ January 4-8 } & \multirow[t]{2}{*}{$\left.{ }^{I}\right|_{\text {Control }} 5$} & 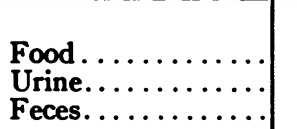 & $\begin{array}{r}\text { grams } \\
14.53 \\
11.96 \\
1.16\end{array}$ & $\begin{array}{r}\text { erams } \\
90.8 \\
7.2\end{array}$ & $\begin{array}{r}\text { grams } \\
79.88 \\
3.53\end{array}$ & $\begin{array}{l}\text { grams } \\
142.2\end{array}$ & $\begin{array}{r}\text { grams } \\
14.57 \\
4.41\end{array}$ \\
\hline & & $\begin{array}{l}\text { Balance........... } \\
\text { Apparent digestibility }\end{array}$ & $\begin{array}{l}+1.41 \\
\text { per cent }\end{array}$ & $\begin{array}{c}83.6 \\
(92.0)\end{array}$ & $\begin{array}{l}76.35 \\
(95.5)\end{array}$ & & $\begin{array}{l}10.16 \\
(69.7)\end{array}$ \\
\hline \multirow[t]{2}{*}{ January $9-15$} & \multirow{2}{*}{\begin{tabular}{|c|} 
II 1 \\
1 to 4 doses 100 to 400 \\
units insulin, 0.125 \\
to 0.50 gram hexyl- \\
resorcinol, pH 10.5
\end{tabular}} & 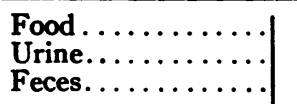 & $\begin{array}{r}14.53 \\
13.27 \\
1.33\end{array}$ & $\begin{array}{r}90.8 \\
8.3\end{array}$ & $\begin{array}{r}79.9 \\
2.7\end{array}$ & $\begin{array}{r}142.2 \\
1.9\end{array}$ & $\begin{array}{r}14.57 \\
4.48\end{array}$ \\
\hline & & $\begin{array}{l}\text { Balance.......... } \\
\text { Apparent digestibility }\end{array}$ & $\begin{array}{l}-0.07 \\
\text {, per cent }\end{array}$ & $\begin{array}{c}82.5 \\
(90.8)\end{array}$ & $\begin{array}{c}77.2 \\
(96.6)\end{array}$ & $\begin{array}{l}140.3 \\
(98.6)\end{array}$ & $\begin{array}{r}10.09 \\
(69.2)\end{array}$ \\
\hline \multirow[t]{2}{*}{ January 16-24 } & \multirow{2}{*}{ 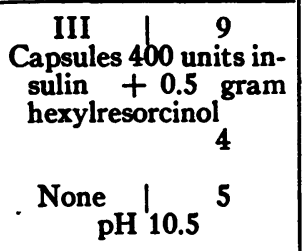 } & 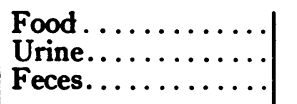 & $\begin{array}{r}14.53 \\
12.92 \\
1.29\end{array}$ & $\begin{array}{r}90.8 \\
8.1\end{array}$ & $\begin{array}{r}79.9 \\
2.3\end{array}$ & $\begin{array}{r}142.2 \\
1.1\end{array}$ & $\begin{array}{r}14.57 \\
4.26\end{array}$ \\
\hline & & $\begin{array}{l}\text { Balance........... } \\
\text { Apparent digestibility }\end{array}$ & $\begin{array}{l}+0.32 \\
, \text { per cent }\end{array}$ & $\begin{array}{c}82.7 \\
(91.0)\end{array}$ & $\begin{array}{l}77.6 \\
(97.1)\end{array}$ & $\begin{array}{l}141.1 \\
(99.2)\end{array}$ & $\begin{array}{l}10.31 \\
(70.7)\end{array}$ \\
\hline \multirow[t]{2}{*}{ January 25-30 } & \multirow{2}{*}{$\begin{array}{l}\text { IV } 1 \text { 6 } 6 \\
4 \text { doses } 800 \text { units in- } \\
\text { sulin }+1.0 \text { gram } \\
\text { hexylresorcinol, pH } \\
10.5\end{array}$} & 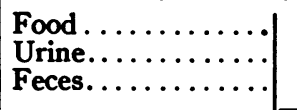 & $\begin{aligned} 14.53 \\
13.91 \\
1.54\end{aligned}$ & $\begin{array}{r}90.8 \\
9.6\end{array}$ & $\begin{array}{r}79.9 \\
2.2\end{array}$ & $\begin{array}{r}142.2 \\
1.3\end{array}$ & $\begin{array}{r}14.57 \\
5.22\end{array}$ \\
\hline & & $\begin{array}{l}\text { Balance............ } \\
\text { Apparent digestibility }\end{array}$ & $\begin{array}{l}-0.92 \\
\text {, per cent }\end{array}$ & $\begin{array}{c}81.2 \\
(89.4)\end{array}$ & $\begin{array}{l}77.7 \\
(97.2)\end{array}$ & $\begin{array}{l}140.9 \\
(99.0)\end{array}$ & $\begin{array}{r}9.35 \\
(64.1)\end{array}$ \\
\hline
\end{tabular}

(Subject M. D.)

\begin{tabular}{|c|c|c|c|c|c|c|c|}
\hline \multirow[t]{2}{*}{ January 4-8 } & \multirow[t]{2}{*}{$\left.{ }^{I}\right|_{\text {Control }} 5$} & \multirow{2}{*}{ 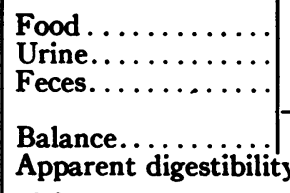 } & $\begin{array}{r}11.59 \\
10.98 \\
1.04\end{array}$ & $\begin{array}{r}72.4 \\
6.5\end{array}$ & $\begin{array}{r}73.1 \\
8.3\end{array}$ & $\begin{array}{r}136.0 \\
2.7\end{array}$ & \multirow[t]{2}{*}{11.48} \\
\hline & & & - 0.43 & $\begin{array}{c}65.9 \\
(91.0)\end{array}$ & $\begin{array}{c}64.8 \\
(88.6)\end{array}$ & $\begin{array}{l}133.3 \\
(98.0)\end{array}$ & \\
\hline \multirow[t]{2}{*}{$\overline{\text { January } 9-15}$} & \multirow{2}{*}{\begin{tabular}{|c|} 
II $~$ \\
1 to 3 doses daily 100 \\
to 300 units insulin, \\
0.125 to 0.375 gram \\
hexylresorcinol, pH \\
10.5
\end{tabular}} & 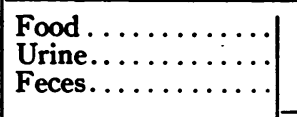 & \begin{tabular}{r|}
13.84 \\
10.99 \\
1.12 \\
\end{tabular} & $\begin{array}{r}86.5 \\
7.0 \\
\end{array}$ & $\begin{array}{r}77.6 \\
2.4 \\
\end{array}$ & $\begin{array}{r}131.9 \\
3.0 \\
\end{array}$ & $\begin{array}{r}12.26 \\
1.32 \\
\end{array}$ \\
\hline & & $\begin{array}{l}\text { Balance........... } \\
\text { Apparent digestibility }\end{array}$ & $\begin{array}{l}+1.73 \\
\text {, per cent }\end{array}$ & $\begin{array}{c}79.5 \\
(91.9)\end{array}$ & $\begin{array}{c}75.2 \\
(96.9)\end{array}$ & $\begin{array}{l}128.9 \\
(97.9)\end{array}$ & $\begin{array}{l}10.94 \\
(89.2)\end{array}$ \\
\hline \multirow[t]{2}{*}{ January $16-24$} & \multirow[t]{2}{*}{$\begin{array}{cc}\text { III } \quad & 9 \\
\text { Capsules, } & 4 \\
\text { No oral, } & 5\end{array}$} & 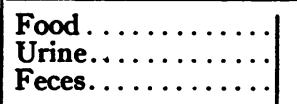 & $\begin{array}{r}13.84 \\
10.71 \\
0.96\end{array}$ & $\begin{array}{r}86.5 \\
6.3\end{array}$ & $\begin{array}{r}77.6 \\
2.6\end{array}$ & $\begin{array}{r}131.9 \\
3.4\end{array}$ & $\begin{array}{r}12.26 \\
1.05\end{array}$ \\
\hline & & $\begin{array}{l}\text { Balance........... } \\
\text { Apparent digestibility }\end{array}$ & $\begin{array}{l}+2.17 \\
\text { per cent }\end{array}$ & $\begin{array}{c}80.2 \\
(92.7)\end{array}$ & $\begin{array}{l}75.0 \\
(96.6)\end{array}$ & $\begin{array}{l}128.5 \\
(97.4)\end{array}$ & $\begin{array}{l}11.21 \\
(91.4)\end{array}$ \\
\hline \multirow[t]{2}{*}{ January 25-30 } & \multirow{2}{*}{\begin{tabular}{|l|} 
IV \\
4 doses daily 800 units \\
insulin, 1.0 gram \\
hexylresorcinol, pH \\
10.5
\end{tabular}} & 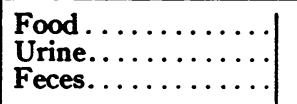 & $\begin{array}{r}13.84 \\
12.54 \\
1.21\end{array}$ & $\begin{array}{r}86.5 \\
7.6\end{array}$ & $\begin{array}{r}77.6 \\
2.4\end{array}$ & $\begin{array}{r}131.9 \\
4.3\end{array}$ & $\begin{array}{r}12.26 \\
0.96\end{array}$ \\
\hline & & $\begin{array}{l}\text { Balance........ } \\
\text { Apparent digestibility }\end{array}$ & $\begin{array}{l}-0.11 \\
\text { per cent }\end{array}$ & $\begin{array}{l}78.9 \\
(91.2)\end{array}$ & $\begin{array}{c}75.2 \\
(96.9)\end{array}$ & $\begin{array}{l}127.6 \\
(96.7)\end{array}$ & $\begin{array}{l}11.30 \\
(92.1)\end{array}$ \\
\hline
\end{tabular}


fectly constant diets during the adjustment period and subsequent experimental periods; (3) strict confinement in the hospital under careful surveillance of a competent special nurse.

\section{Effect on digestion}

At the beginning of this work it was felt that the degree of interference, if any, of the controlling substances with total digestion must be known in order that a proper assay of the effectiveness of the insulin might be given. If, for example, the high $\mathrm{pH}$ of the mixture or the hexylresorcinol should interfere materially with digestion or absorption of carbohydrate or protein, a diminution in the excretion of sugar might be attributed erroneously to the oral insulin.

Two subjects, therefore, were placed on the rigidly controlled diet. A fecal marker was given with the first breakfast in each period and another with the first breakfast following the experiment. Feces were collected from the first appearance of one mark to the first appearance of the next. There was an occasional loose stool, but with only one exception this occurred after a period was well started and in the single instance mentioned no difficulty was found in making satisfactory separation.

Precisely one half the day's diet on two separate days was weighed out, in addition to the amount served, and this half-portion was dried down for analysis. Food and feces were analyzed by identical methods for total nitrogen, total fat (ether extract), total ash and total hydrolyzable sugar, expressed as glucose. Total carbohydrate was also found in the food by subtraction. Twenty-four-hour urines were collected and analyzed for total nitrogen and total sugar.

In Table $I$, the resulting figures are given as well as the $\mathrm{N}$-balance and the apparent digestibility expressed as percentages of each nutrient fed. The term "apparent digestibility" is used as the equivalent of the older term "coefficient of utilization" or " coefficient of absorption." It gives recognition to the fact that there is an endogenous excretion of nitrogen from the gut (now called alimentary nitrogen) which should be subtracted from fecal nitrogen to give the true food nitrogen remaining unabsorbed. The apparent digestibility serves equally well for the pur- pose in hand. No material retardation of digestion or absorption can escape, and to obtain true digestibility would require at least one period of several days without any protein in the diet, a procedure which we hesitated to impose on a diabetic.

The periods for subjects T. L. and M. D. coincided. Period I, of five days' duration, was a control, no oral insulin being given. In Period II from one to three standard doses were given, each consisting of $200 \mathrm{cc}$. of water in which were dissolved 100 units of insulin, 0.125 per cent of hexylresorcinol, and a mixture of sodium carbonate and bicarbonate sufficient to give a $\mathrm{pH}$ of 10 to 10.5. Period III started out to be one in which the same quantity of insulin and adjuvant substances in dry form for each dose would be taken in a gelatin capsule. These capsules were not successful and produced nausea; consequently, they were discontinued at the end of four days. The period continued, however, for five days longer without any insulin. Then followed Period IV during which for six days a double dose (200 units plus corresponding amounts of hexylresorcinol and sodium salts) was given four times each day, making a total of 800 clinical units and 1.0 gram hexylresorcinol.

It is readily seen (Table I) that no material difference in the apparent digestibility of the protein, fat or carbohydrate occurred as between the period with no insulin and either of those with insulin and the adjuvant chemicals. Changes equally great occur in successive periods on any weighed and analyzed diet which is constant. There is, however, with one exception a slightly greater output of nitrogen in the full oral-insulin periods. Since this concerns the urine principally, it could not be attributed to lessened digestion but rather to faulty retention.

The only change which is consistent throughout all the comparisons is a slightly better absorption of fat when the hexylresorcinol was given. The difference in the first comparison with subject T. L. was only 1 per cent, but with subject M. D. it was over 8 per cent. The better absorption of fat is readily explained by the emulsifying action of hexylresorcinol, this same property (surface tension lowering) possibly affecting also the absorption of insulin. Carbohydrate (expressed as 
hydrolyzed glucose), the component of the diet about which we were especially concerned, shows no material change in absorption either way. The absorption of the ash was rather low in subject T. L.-notably so in the last period. But no consistent adverse effect of the oral mixture is to be made out. Two other subjects studied for a shorter time in the same manner gave the same evidence of non-interference with digestion.

Naturally these findings were reassuring and we have not hesitated since then to give up to four double doses of the insulin-hexylresorcinolalkaline salts mixture (800 I. U.) each day. There have been no signs of interference with digestion and very little interference with appetite (see H. G., Table II) in any of the subjects so long as the solutions described were used. Gelatin capsules containing hexylresorcinol in dry form sometimes have produced nausea and in certain instances, when sufficient water has not been taken, they have been regurgitated. Enteric coated tablets containing insulin and the adjuvant materials have not as yet been proved to have any comparable effect. The results described below apply, with certain exceptions noted, only to the effects of insulin given in solutions.

\section{PROCEDURE}

Each patient on admission was placed on a controlled diet, estimated to be sufficient to maintain body weight, with some deficiency of insulin, in the ambulatory hospital life he was expected to lead. More than half the patients were bedded in the regular medical divisions of Strong Memorial Hospital, but five of the twelve and some others were cared for in the metabolism unit of the Department of Medicine where facilities for close observation of the patient and feeding from the metabolism kitchen were available. At times patients in the regular divisions were given their meals in the Department of Vital Economics from its own diet kitchen. This required only a walk up one flight and into an adjoining wing of the medical school. No patient was allowed to leave the hospital during an experiment or to leave the prescribed limits without permission in each instance. A recreation room was fitted up in the Department of Vital Economics where men patients bedded in the divisions could listen to the radio, smoke, and play games. In the metabolism unit, also, radio receiving sets were provided in the rooms and smoking was permitted so long as the patient remained strictly in his room.

The nurse in charge of the cases in the division or metabolism unit, as the case might be, exercised watchful care over the collections of urines in definite periods, the administration of subcutaneous insulin, etc. at all times. When it was necessary to give subcutaneous insulin at night to patients in the metabolism unit, this was done by a night nurse from an adjoining division of the hospital. Meal times were kept regular, and a special dietitian prepared the food, weighed all food served, and weighed back anything left on the plate. Diets were kept as nearly constant as the variations from standard food tables would permit. The task of analyzing all foods consumed was too great to be undertaken. Reliance was placed on long periods, or repetition a sufficient number of times, to equalize variations and give dependable averages.

Oral insulin works best on an empty stomach, and with the idea that two meals a day, without change of total or distributed calories, might afford greater chance of absorption, this alteration was made for a short time with two patients (P. J. and W. V.), but there was no greater total effect (see W. V., Table II). The twomeal method with oral insulin a short time before each meal would probably have given greater results with some of the more responsive subjects.

In the adjustment of subcutaneous insulin to a level which would permit excretion of sufficient sugar for reliable determinations both qualitatively and quantitatively, it was, of course, necessary to proceed with caution both as regards the total insulin given and the distribution. The requirement of a hospitalized patient decreases considerably below that of the patient at home, in most cases, and the danger of insulin shock is correspondingly increased. The number of times shock occurred was very small. The greater difficulty arose from the change from protamine-zinc insulin to regular insulin, and in two cases (H. C. and T. V.) it was necessary to continue the protamine-zinc variety throughout. If the work were being planned again, it is believed that the use of protamine-zinc insulin might be made the basis of a more accurate confirmatory assay from the fasting blood sugar levels. (See section on Unitage Effects below.) From early experiments, however, it was found, as expected, that readjustments of the subcutaneous insulin could be made much more rapidly with regular insulin, and this time factor seemed all important. It was known also that some patients cannot tolerate the protamine-zinc mixture. Hence, for uniformity and dependability of results, the use of regular insulin whenever possible was decided upon.

The insulin employed for oral administration also was regular insulin, generously contributed in the form of highest purity powders or crystals by the manufacturers. The administration of the oral doses was always supervised by one of the authors. From experiments on themselves and other normal volunteers, as well as from experiments on dogs $(1,2,3)$, they knew that the insulin must be mixed with the hexylresorcinol-buffer mixture immediately before administration to be sure of its survival long enough for absorption. Data on the survival of insulin under various conditions pertinent to this study will be found in the earlier publications. Aqueous solutions of the dry insulin of varying unitage were pre- 
pared, based on the assays supplied by the manufacturers and, in many instances, on confirmatory assays on rabbits, made in our laboratories. As in the dog experiments (3), the "standard dose" came to be $100 \mathrm{I}$. U. insulin dissolved in a solution of 0.125 per cent hexylresorcinol and sufficient buffer mixture to give a final $p H$ of 10 to 10.5 , the total volume being $200 \mathrm{cc}$. Where a "double dose" is mentioned, it means two standard doses. If the volume were increased for any reason, the other solutes were increased correspondingly. Trials were made at times of 0.25 per cent solution of hexylresorcinol, but with no better results. In this work on human diabetics no mixture was given which had not already been proved potent in the animal work.

From experiments on normal subjects it was thought for a time that solutions in 10 to 20 per cent alcohol instead of water were more effective and these were tried in a few instances on the human cases, with their consent, but there was no improvement. Repetition on normals completed the disillusionment. Various flavor- ing substances also were used to mitigate the rather biting, astringent effect of hexylresorcinol in the mouth, which to some subjects was unpleasant.

\section{Urine and blood}

Urines were collected every day in four periods : 7 to 11 a.m., 11 to 4 p.m., 4 to 9 p.m., and 9 p.m. to 7 a.m. The conventional eight drops were used for qualitative tests in all these fractions according to the Benedict method, and the results recorded as $0,1+, 2+, 3+$, and $4+$. These checks proved invaluable in adjusting the daily distribution of subcutaneous insulin as well as in gauging the effects of oral dosage.

In the quantitative determination of glucose in the urine, the copper-iodometric method of Shaffer and Somogyi (6) was used after treatment with the $\mathrm{HgSO}_{4}$ $\mathrm{BaCO}_{3}$ reagent devised by West, Scharles, and Peterson (7) for removal of interfering substances.

As soon as the patient began to show a reasonably constant level of urine sugar, bloods were drawn by one

TABLE II

Effect of oral insulin on urine sugar and on fasting blood sugar

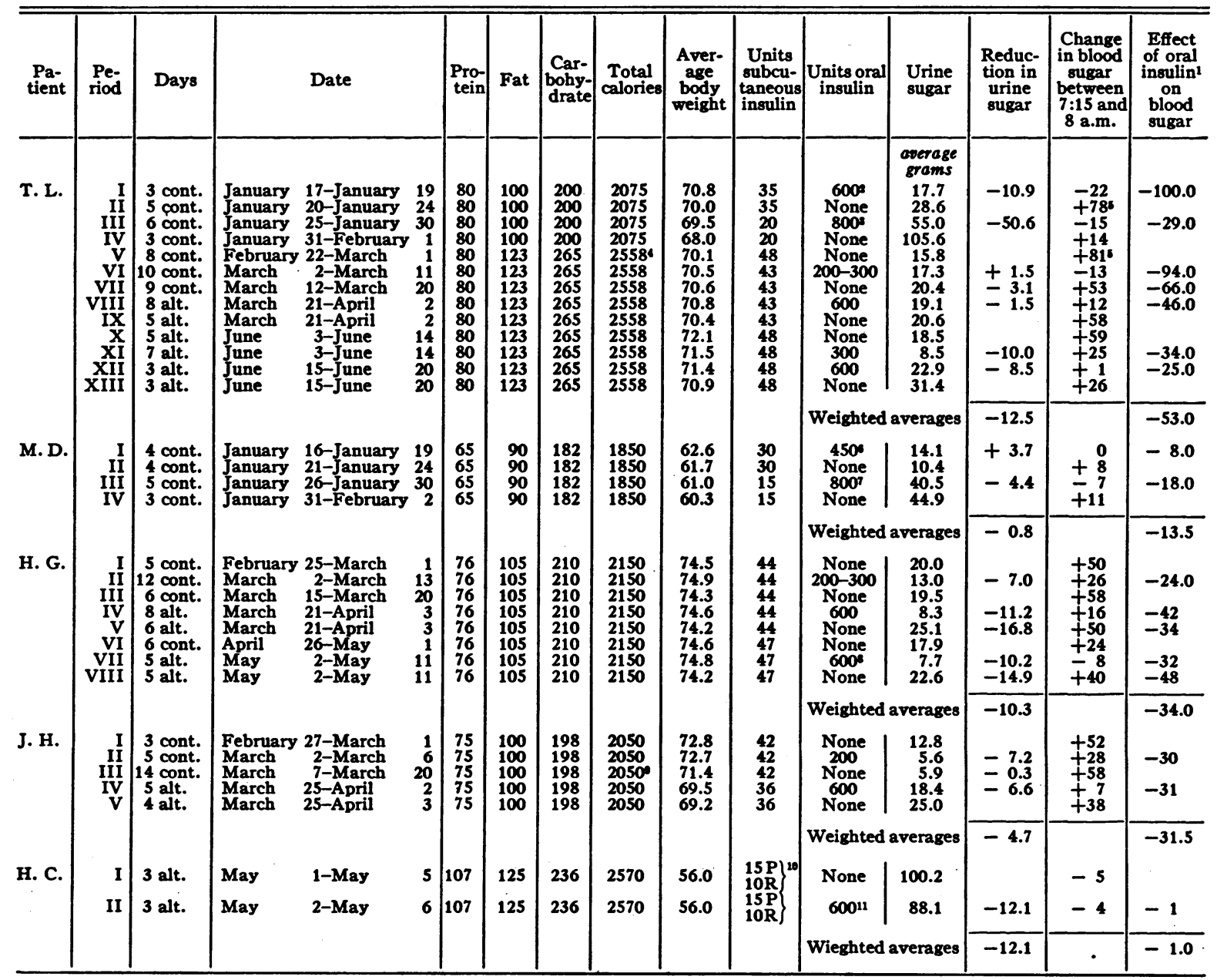


TABLE II-Continued

\begin{tabular}{|c|c|c|c|c|c|c|c|c|c|c|c|c|c|c|c|c|}
\hline$\underset{\text { tient }}{\mathrm{Pa}-}$ & $\begin{array}{l}\text { Pe- } \\
\text { riod }\end{array}$ & Days & & Date & & $\begin{array}{c}\text { Pro- } \\
\text { tein }\end{array}$ & Fat & $\left|\begin{array}{l}\text { Car- } \\
\text { bohy } \\
\text { drate }\end{array}\right|$ & $\begin{array}{c}\text { Total } \\
\text { calories }\end{array}$ & $\begin{array}{c}\text { Aver- } \\
\text { age } \\
\text { body } \\
\text { weight }\end{array}$ & $\begin{array}{c}\text { Units } \\
\text { subcu- } \\
\text { taneous } \\
\text { insulin }\end{array}$ & $\begin{array}{c}\text { Units oral } \\
\text { insulin }\end{array}$ & $\begin{array}{l}\text { Urine } \\
\text { sugar }\end{array}$ & $\begin{array}{l}\text { Reduc- } \\
\text { tion in } \\
\text { urine } \\
\text { sugar }\end{array}$ & $\begin{array}{l}\text { Change } \\
\text { in blood } \\
\text { sugar } \\
\text { between } \\
7: 15 \text { and } \\
8 \text { a.m. }\end{array}$ & $\begin{array}{c}\text { Effect } \\
\text { of oral } \\
\text { insulin } \\
\text { on } \\
\text { blood } \\
\text { sugar }\end{array}$ \\
\hline L. P. & II & $\begin{array}{l}4 \text { cont. } \\
4 \text { cont. }\end{array}$ & $\begin{array}{l}\text { June } \\
\text { June }\end{array}$ & $\begin{array}{l}\text { 12-June } \\
\text { 16-June }\end{array}$ & $\begin{array}{l}15 \\
19\end{array}$ & $\begin{array}{l}90 \\
90\end{array}$ & $\begin{array}{l}120 \\
120\end{array}$ & $\begin{array}{l}238 \\
238\end{array}$ & $\begin{array}{l}2460 \\
2460\end{array}$ & $\begin{array}{l}71.8 \\
71.3\end{array}$ & $\begin{array}{l}15 \\
15\end{array}$ & $\begin{array}{c}300-600 \\
\text { None }\end{array}$ & $\begin{array}{c}\text { average } \\
\text { erams } \\
3.8 \\
14.1\end{array}$ & -10.3 & $\begin{array}{l}-10 \\
+7\end{array}$ & -17 \\
\hline \multirow[t]{2}{*}{ T. V. } & I & 4 alt. & May & 8-May & 14 & 82 & 100 & 184 & 2020 & 39.5 & $\begin{array}{l}15 \mathrm{P} \\
25 \mathrm{R}\end{array}$ & & 26.6 & -15.7 & -15 & -28 \\
\hline & II & 3 alt. & May & 8-May & 14 & 82 & 100 & 184 & 2020 & 39.4 & $\left.\begin{array}{l}15 \mathrm{P} \\
25 \mathrm{R}\end{array}\right\}$ & None & 42.3 & & +13 & \\
\hline \multirow[t]{2}{*}{ F. 0 . } & $\begin{array}{c}\text { II } \\
\text { III } \\
\text { IV } \\
\mathbf{v} \\
\text { vI } \\
\text { vIII } \\
\text { vIII }\end{array}$ & $\begin{array}{l}5 \text { cont. } \\
6 \text { cont. } \\
5 \text { cont. } \\
2 \text { alt. } \\
5 \text { alt. } \\
6 \text { cont. } \\
6 \text { ael. } \\
4 \text { sel. }\end{array}$ & $\begin{array}{l}\text { January } \\
\text { January } \\
\text { January } \\
\text { January } \\
\text { January } \\
\text { February } \\
\text { February } \\
\text { February }\end{array}$ & $\begin{array}{l}\text { 13-January } \\
\text { 18-January } \\
\text { 25-January } \\
\text { 318February } \\
\text { 30-February } \\
\text { 6-February } \\
\text { 19-February } \\
\text { 23-March }\end{array}$ & $\begin{array}{r}17 \\
24 \\
29 \\
2 \\
5 \\
11 \\
27 \\
2\end{array}$ & \begin{tabular}{|l|}
78 \\
78 \\
78 \\
78 \\
78 \\
78 \\
79 \\
79
\end{tabular} & $\begin{array}{l}107 \\
107 \\
107 \\
107 \\
107 \\
107 \\
110 \\
110\end{array}$ & $\begin{array}{l}177 \\
177 \\
177 \\
177 \\
177 \\
177 \\
205 \\
205\end{array}$ & $\begin{array}{l}1980 \\
1980 \\
1980 \\
1980 \\
1980 \\
1980 \\
2200 \\
2200\end{array}$ & $\begin{array}{l}50.0 \\
50.1 \\
49.4 \\
49.4 \\
49.5 \\
49.3 \\
49.9 \\
49.8\end{array}$ & $\begin{array}{l}10 \\
10 \\
10 \\
10 \\
10 \\
10 \\
25 \\
25\end{array}$ & $\begin{array}{c}\text { None } \\
100-300 \\
\text { None } \\
\text { None } \\
400 \\
800 \\
\text { None } \\
200\end{array}$ & \begin{tabular}{|l|}
12.3 \\
13.6 \\
36.4 \\
51.3 \\
31.9 \\
34.0 \\
15.9 \\
5.6
\end{tabular} & $\begin{array}{l} \pm 1.3 \\
-22.8 \\
-19.4 \\
-17.3 \\
-10.3 \\
\end{array}$ & $\begin{array}{l}-1012 \\
-68 \\
=3 \\
=14 \\
-76 \\
-73 \\
=2 \\
-42 \\
\end{array}$ & $\begin{array}{l}-58 \\
-65 \\
-62 \\
-71 \\
-4010\end{array}$ \\
\hline & & & & & & & & & & & & Weighted a & averages & -17.7 & & -60 \\
\hline \multirow[t]{2}{*}{ P. F. } & $\begin{array}{c}\text { II } \\
\text { III } \\
\text { IV } \\
\mathbf{v}\end{array}$ & $\begin{array}{l}4 \text { cont. } \\
7 \text { cont. } \\
5 \text { cont. } \\
2 \text { cont. } \\
5 \text { sel. }\end{array}$ & $\begin{array}{l}\text { January } \\
\text { January } \\
\text { January } \\
\text { January } \\
\text { January }\end{array}$ & $\begin{array}{l}\text { 14-January } \\
\text { 18-January } \\
\text { 25-January } \\
\text { 31\&February } \\
\text { 30-February }\end{array}$ & $\begin{array}{r}17 \\
24 \\
29 \\
2 \\
5\end{array}$ & $\begin{array}{l}69 \\
69 \\
69 \\
69 \\
69\end{array}$ & $\begin{array}{l}100 \\
100 \\
100 \\
100 \\
100\end{array}$ & \begin{tabular}{l|}
147 \\
147 \\
147 \\
147 \\
147
\end{tabular} & $\begin{array}{l}1764 \\
1764 \\
1764 \\
1764 \\
1764\end{array}$ & $\begin{array}{l}65.1 \\
65.0 \\
64.0 \\
63.9 \\
64.0\end{array}$ & $\begin{array}{l}45 \\
45 \\
45 \\
45 \\
45\end{array}$ & $\left|\begin{array}{c}\text { None } \\
100-300 \\
\text { None } \\
\text { None } \\
400\end{array}\right|$ & $\begin{array}{r}8.7 \\
4.9 \\
16.0 \\
22.7 \\
11.2\end{array}$ & $\begin{array}{r}-3.8 \\
-11.1 \\
-11.5 \\
\end{array}$ & $\begin{array}{l}+21 \\
-10 \\
+8 \\
+1 \\
-23 \\
\end{array}$ & $\begin{array}{l}-31 \\
-18 \\
-24 \\
\end{array}$ \\
\hline & & & & & & & & & & & & Weighted a & averages & -9.1 & & -24 \\
\hline \multirow[t]{2}{*}{ P. J. } & 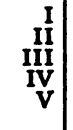 & $\begin{array}{l}2 \text { cont. } \\
2 \text { cont. } \\
3 \\
3 \text { cont. } \\
3 \text { cont. } \\
\text { cont. }\end{array}$ & $\begin{array}{l}\text { June } \\
\text { June } \\
\text { June } \\
\text { July } \\
\text { July }\end{array}$ & $\begin{array}{r}23 \& 24 \\
25 \& 26 \\
28-J u n e \\
1-J u l y \\
5-J u l y\end{array}$ & $\begin{array}{r}30 \\
\mathbf{3} \\
7\end{array}$ & $\begin{array}{l}62 \\
62 \\
62 \\
62 \\
62\end{array}$ & $\begin{array}{l}80 \\
80 \\
80 \\
80 \\
80\end{array}$ & \begin{tabular}{|l|}
158 \\
158 \\
158 \\
158 \\
158
\end{tabular} & $\begin{array}{l}1646 \\
1646 \\
1646 \\
1646 \\
1646\end{array}$ & $\begin{array}{l}61.2 \\
61.5 \\
61.4 \\
61.5 \\
61.3\end{array}$ & $\begin{array}{l}20 \\
20 \\
20 \\
20 \\
15\end{array}$ & $\begin{array}{c}\text { None } \\
200 \\
\text { None } \\
200 \\
\text { None }\end{array}$ & $\begin{array}{r}31.7 \\
17.8 \\
17.0 \\
8.2 \\
19.1\end{array}$ & $\begin{array}{r}-13.9 \\
-8.8\end{array}$ & 14 & \\
\hline & & & & & & & & & & & & Weighted & average & -10.8 & & \\
\hline E. $\mathbf{w}$. & II & $\begin{array}{l}3 \text { sel. } \\
4 \text { sel. }\end{array}$ & $\begin{array}{l}\text { June } \\
\text { June }\end{array}$ & $\begin{array}{l}18,20,21 \& \\
17,19,23 \&\end{array}$ & $\begin{array}{l}22 \\
24\end{array}$ & $\begin{array}{l}60 \\
60\end{array}$ & $\begin{array}{l}70 \\
70\end{array}$ & $\begin{array}{l}135 \\
135\end{array}$ & $\begin{array}{l}1230 \\
1230\end{array}$ & $\begin{array}{l}54.3 \\
54.4\end{array}$ & $\begin{array}{l}40 \\
40\end{array}$ & $\begin{array}{l}\text { None } \\
200\end{array}$ & $\begin{array}{r}13.3 \\
4.4\end{array}$ & -8.9 & $\begin{array}{l}+22 \\
-28\end{array}$ & -50 \\
\hline \multirow[t]{2}{*}{ w. v. } & II & $\begin{array}{l}3 \text { sel. } \\
4 \text { sel. } \\
3 \\
3 \text { sel. } \\
3 \text { cont. }\end{array}$ & $\begin{array}{l}\text { June } \\
\text { June } \\
\text { July } \\
\text { July }\end{array}$ & $\begin{array}{c}26,27 \text { \& } 29 \\
28,30, \text { July } 18 \\
7,8 \text { \& } 12 \\
9-J u l y\end{array}$ & $\begin{array}{l}\& 2 \\
11\end{array}$ & \begin{tabular}{|l|}
70 \\
70 \\
82 \\
82
\end{tabular} & $\begin{array}{l}105 \\
105 \\
101 \\
101\end{array}$ & $\begin{array}{l}210 \\
210 \\
217 \\
217\end{array}$ & $\begin{array}{l}2120 \\
2120 \\
212015 \\
2120^{13}\end{array}$ & $\begin{array}{l}70.4 \\
70.4 \\
69.8 \\
69.8\end{array}$ & $\begin{array}{l}25 \\
25 \\
15 \\
15\end{array}$ & $\begin{array}{c}\text { None } \\
200 \\
\text { None } \\
400\end{array}$ & $\begin{array}{r}15.0 \\
8.1 \\
7.7 \\
4.4\end{array}$ & $\begin{array}{r}-6.9 \\
-3.3 \\
\end{array}$ & $\begin{array}{l} \pm 8 \\
-21 \\
-25 \\
-25\end{array}$ & $\begin{array}{l}-29 \\
-21 \\
\end{array}$ \\
\hline & & & & & & & & & & & & \multicolumn{2}{|c|}{ Weighted averages } & -5.4 & & -26 \\
\hline
\end{tabular}

Summary of results of oral insulin in twelve diabetic patients of varying degrees of severity. Diets and subcutaneous insulin held constant in control periods, designated "none" under "Units oral insulin," and periods with varying quantities of oral insulin. This was administered in solution with 0.125 per cent hexylresorcinol and a buffering solution giving a $\mathrm{pH}$ to the whole mixture of 10 to 10.5 . In third column "cont." means continuous days, "alt." means alternating on and off oral insulin, "sel." means selected days mostly continuous.

1 Effect of first dose only. $\quad 2+2$ enteric tablets on 3 days.

28 capsules 75 I.U. each.

Same since February 6.

$7+2$ enteric tablets on 3 days. Refused 250 calories on March 4 and March 5.

1800 I.U. thiamin chloride on May 6, May 8 and May 10.

- Plus orange juice for reaction on March 23 and March 24.

${ }_{10} \mathrm{P}=$ protamine insulin; $\mathrm{R}=$ regular insulin.

is 3 doses each preceded by 2 capsules containing sodium taurocholate on May 2 and May 4. 4800 I.U. thiamin chloride on May 6.

1 Bloods taken on 2 days only.

is Sorensen mixture for sake of R.Q.

of the authors every morning soon after 7 a.m., and this procedure was continued throughout each experimental period on or off oral insulin, conditional only on the status of the patient's veins. Sugar was determined by the Shaffer-Somogyi (6) technique after precipitation with the Somogyi (8) zinc-hydroxide reagent.

For gauging the effects of oral insulin on blood sugar, the first dose was given immediately after this first fasting blood was drawn, and a second sample was drawn forty-five minutes to one hour later and fifteen minutes
14 Veins too small to get blood.

4 Two meals only at 9 a.m. and 4 p.m. before the subject's breakfast. The "change in blood sugar between 7:15 and 8 a.m." described in Table II refers to the change from the first to the second of these two samples. The average time was as noted in the heading but, owing to difficulty in getting blood in some patients, there were minor variations in this interval. Frequently, bloods were drawn before and after oral doses taken later in the day, and sometimes the second showed a marked drop in sugar, but as a rule the early morning test gave the greater response. 
Results on urine sugar and fasting blood sugar

In Table II will be found complete data on the twelve patients who showed the most positive absorptions. The significant figures are contained in the last three columns but, before discussing those results in detail, a few more words are necessary in explanation of the earlier .columns. There were two methods of comparing days with and days without oral insulin. First, a period of several consecutive days on oral insulin, as in the first two cases of Table II, followed by several days on the same diet and the same subcutaneous insulin distributed in the same manner. Sometimes the order was reversed as in the second two cases. The dates in Column 4 will enable the reader to see how the two periods were related in time. The second method consisted of alternating successive days, one on, the next off oral insulin, with all other conditions identical. The column of dates shows that the two groups of days compared fell in the same total period. All such comparisons are designated "alt." in the table. Sometimes a period which was intended to be continuous had to be interrupted and became alternating or changed otherwise. These are designated "sel.," meaning selected days, most of which were continuous.

The figures for grams protein, fat and carbohydrate must not be construed too literally. According to food tables these figures actually were constant, but everyone knows that foods vary from the average figures given in tables in both directions. They should be interpreted, therefore, as coming within these variations. The only safeguard aside from actual analysis is always to purchase foods of the same brand or variety. This practice was adhered to very rigidly, thus narrowing the variation as much as possible.

A criterion of adequacy of the diet in relation to the subcutaneous insulin is found in the body weight. For example, it is quite evident that 20 I. U. of subcutaneous insulin in relation to his diet was not adequate for $T$. $L$. in the third and fourth periods. His weight fell $0.5 \mathrm{kgm}$. in the third period when oral insulin was being taken, but it fell $1.5 \mathrm{kgm}$. in the following period with no oral insulin. The output of sugar in the urine obviously went up for the same reason. The experiment was cut short at that point, and the pa- tient was given three weeks to become established at a higher insulin level and on a higher diet. $\mathrm{He}$ also became more active in this subsequent period.

Subject M. D., who was being studied at the same time, exhibits the same picture of inadequacy in Periods III and IV. His weight did not change so much because his subcutaneous insulin was nearer his requirement, even at the lower level. Also, he did not derive as much benefit from oral insulin.

Other instances of weight change, though of lesser magnitude as a rule, may be accounted for in the same manner.

The units of insulin in both columns are always international units (I. U.) and the figures are for twenty-four hours.

In the urine sugar column of figures several features become evident almost at a glance: (1) There is considerable variability intra-individually as between different periods with no oral insulin, even when the subcutaneous insulin is constant. (2) The effect of the same total intake of oral insulin is variable for the individual, even when diet and subcutaneous insulin remained constant (e.g. P. J.). Sometimes, however, there is fair agreement (e.g. H. G.). (3) Finally, the oral insulin, like subcutaneous insulin, has its greatest effect when the initial urine sugar is high (see especially subjects $T$. L. and F. O.) rather than when it is low.

The first type of variability is explained in part by the principle of accumulating deficits. Lack of insulin today should be made up tomorrow. If this does not take place, the sugar excretion tomorrow will be still higher than today. The failure of oral insulin in the intervening periods to make up the deficit of subcutaneous insulin obviously leaves the subject behind, though not so far behind as if he had had no oral dose. Sometimes the effect of the oral dose is quite signicant but, of course, very small in relation to the number of units taken. Variability in the effect from the same number of units taken orally might be explained in part also by the accumulated deficits, but in the instance of P. J. it probably is due in some measure to improvement with rest in the hospital. Twenty units were far from adequate in Period I but, helped by the intervening 


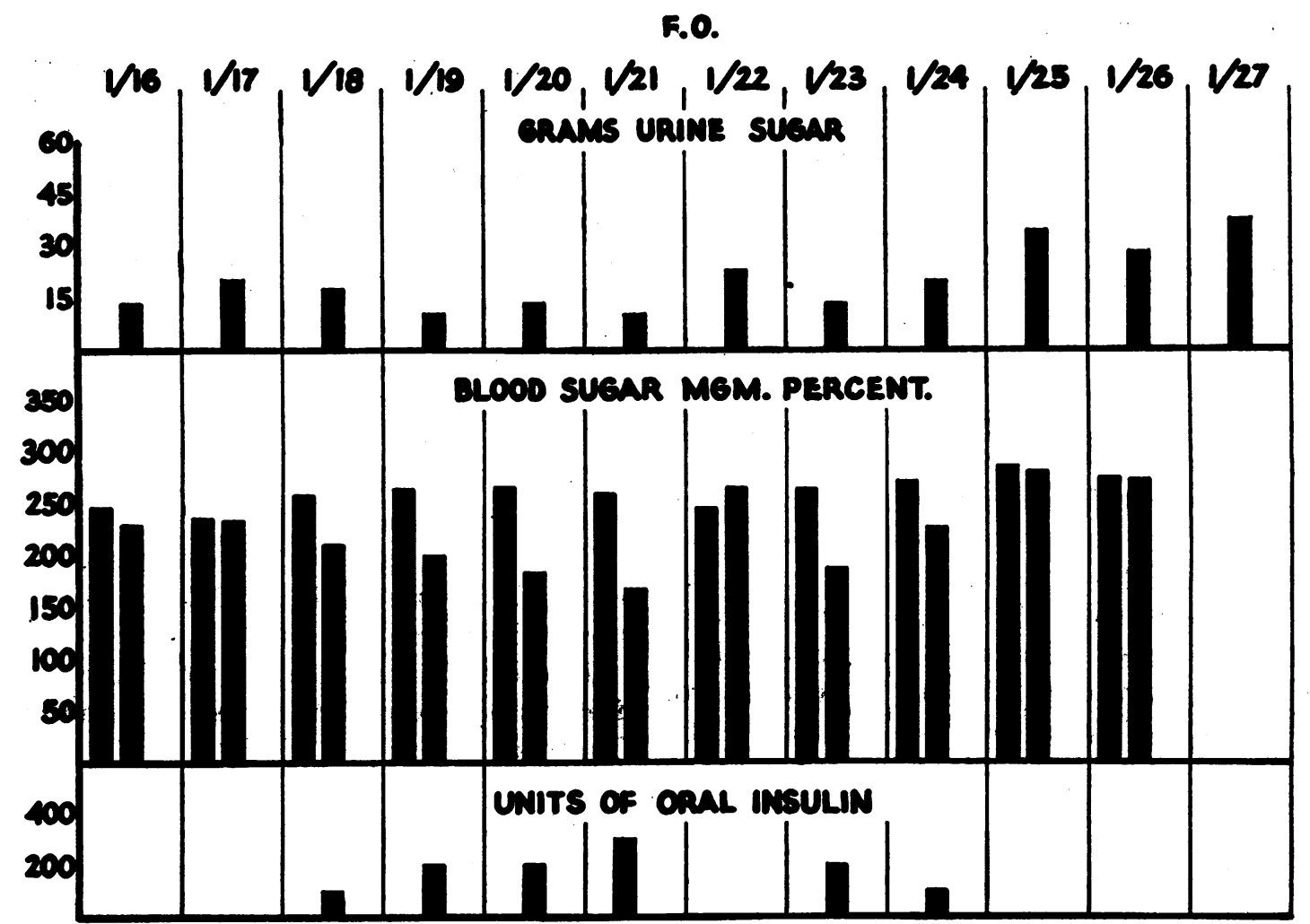

Fig. 1. Daily Record of Urine Sugar and Blood Sugar Changes for Patient F. O., With and Without Oral Insulin, All Other Conditions Remaining Constant

The urine sugar is in 24-hour amounts. The blood sugars shown are: first bar, before oral insulin; second bar, 45 minutes after oral insulin, or at corresponding intervals when oral insulin was not given.

200 units of oral insulin, they had become more nearly so in Period III. Food intake was constant, but the patient's condition had changed.

There is, so to speak, a self-limiting consequence of accumulated deficits in the sense that, in terms of sugar saved, the body makes better use of any given dose of insulin when the wastage is great than when it is small. A muscle " knows how " to adapt itself to a load. Why should not the liver exhibit the same "intelligence"?

Weighted averages. The significant figure showing the effect of oral insulin on urine sugar for each individual case is the figure opposite the words "weighted averages." This figure is obtained by multiplying each of the figures indicating change in urine sugar, immediately above, by the number of days on oral insulin which that figure represents. The algebraic sum is, then obtained and divided by the total number of days on insulin. In each of the cases listed in this table, there is a net reduction in urine sugar which is measurable and which, under the circumstances of the experiment (with the exception of M. D.), is believed to be significant.

The largest effect was obtained with patient F. O., who tolerated the oral insulin remarkably well and also gave results which were nearly proportional to the amount of oral insulin administered (see Figure 1). Very good effects were also obtained on patient H. G. (see Figure 2). These two subjects were the most consistent ones of the entire list in the character of their reactions. Patient T. L. was longest under the treatment with oral insulin, but his reaction was quite variable, as may be observed from the figures opposite the several oral periods. It is obvious from these results on urine sugars that oral insulin given in the manner described has but little effect on urine sugar, except when the urine sugar is quite high ; that, in general, the result is not pro- 


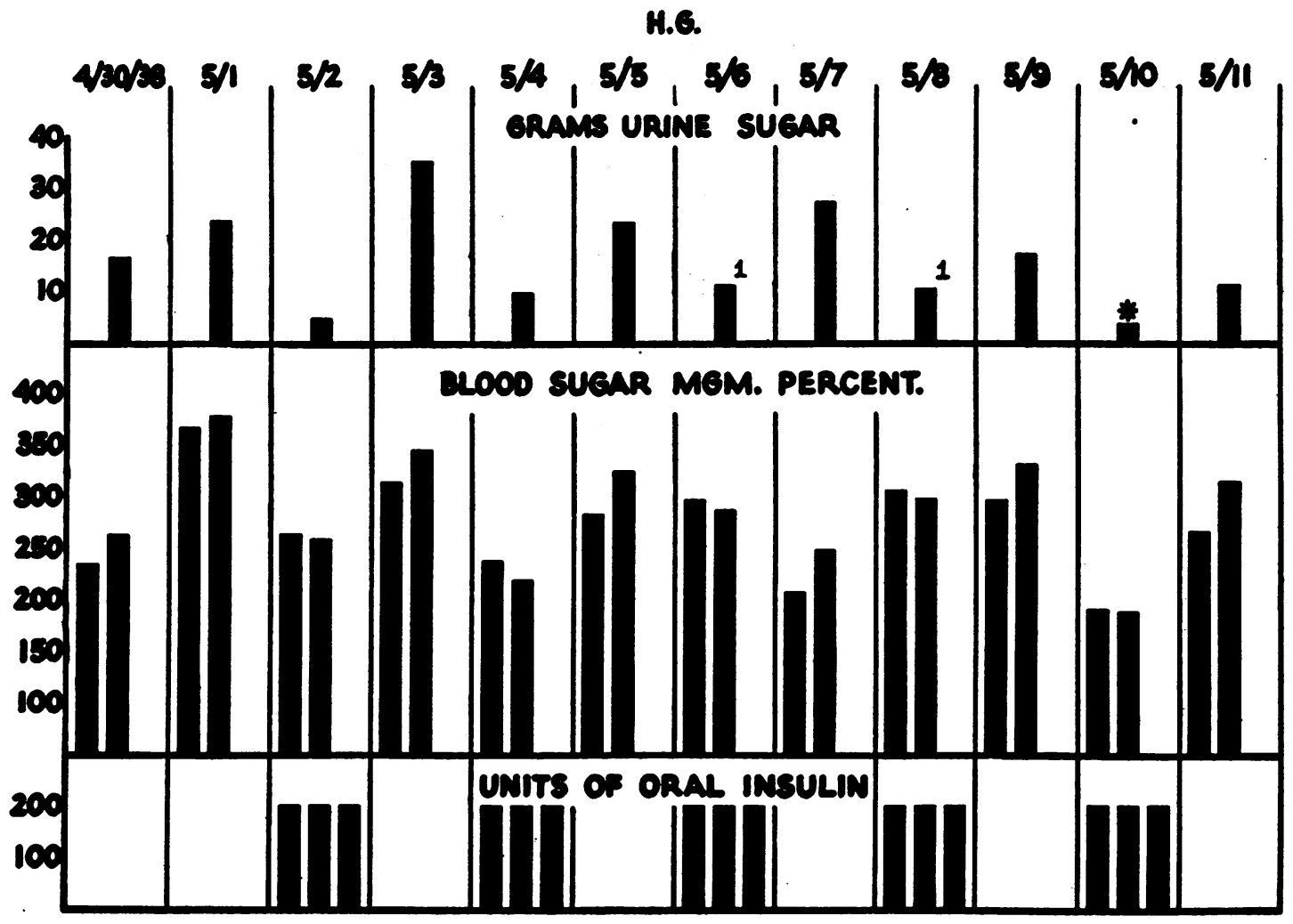

Fig. 2. Daily Record of Urine Sugar and Blood Sugar Changes for Patient H. G., With and Without Oral Insulin, All Other Conditions Remaining Constant

The urine sugar is in 24-hour amounts. The blood sugars shown are: first bar, before oral insulin; second bar, 45 minutes after oral insulin, or at corresponding intervals when oral insulin was not given.

1 Indicates $1500 \mathrm{I}$. U. thiamin chloride with each dose. * Indicates not entire amount of urine sugar.

portional to dosage; and that only very mild cases could hope to replace subcutaneous insulin with oral insulin as here administered.

Change in blood sugar. The change in blood sugar from a single dose of oral insulin is at times very striking. For example, in the first test with patient T. L., the average effect on the blood sugar of a single dose taken early in the morning was 100 milligrams' reduction; the weighted average for all the tests on this patient was 53 milligrams' net reduction. In most of the tests this patient showed a rising blood sugar in the early morning when oral insulin was not given. When it was given, the fasting blood sugar took a downward turn, actually falling between first and second bloods, or the rise was very much diminished, giving in either case a net reduction of considerable magnitude. The same sort of behavior is illustrated by several other patients. With patient F. O., however, it will be observed that the fasting blood sugar was falling between the two blood samples in the early morning when no oral insulin was given, but when oral insulin was given it fell much farther, and the average reduction with this case was $60 \mathrm{mgm}$. per cent in the period between the two blood samples. It should be borne in mind that the oral insulin was given immediately after the first fasting blood sugar. There would be no point in giving a grand average net reduction of fasting blood sugar by means of oral insulin for all of the cases. Only one patient, H. C., failed to show a significant drop with the oral insulin, and this may be connected with the circumstance that he was receiving protamine insulin throughout the experiment. 
TABLE III

Effect of oral insulin in terms of subcutaneous insulin (regular)

\begin{tabular}{|c|c|c|c|c|c|c|c|c|c|c|c|c|}
\hline \multirow{2}{*}{ Patient } & \multicolumn{4}{|c|}{$\begin{array}{l}\text { Average grams urine sugar- } \\
\text { subcutaneous test }\end{array}$} & \multirow{2}{*}{$\begin{array}{l}\text { A } \\
\text { Differ- } \\
\text { ence in } \\
\text { subcu- } \\
\text { taneous } \\
\text { insulin }\end{array}$} & \multirow{2}{*}{$\begin{array}{c}\text { B } \\
\text { Grams } \\
\text { sugar* }\end{array}$} & \multicolumn{4}{|c|}{$\begin{array}{c}\text { Average grams urine sugar- } \\
\text { oral test }\end{array}$} & \multirow{2}{*}{$\begin{array}{l}\text { C } \\
\text { Differ- } \\
\text { ence } \\
\text { due to } \\
\text { oral } \\
\text { insulin }\end{array}$} & \multirow{2}{*}{$\begin{array}{c}\text { Equiva- } \\
\text { lentt } \\
\text { effect } \\
\text { in subcu } \\
\text { taneous } \\
\text { units }\end{array}$} \\
\hline & $\begin{array}{l}\text { 1st } \\
\text { period }\end{array}$ & $\begin{array}{c}\text { Number } \\
\text { days }\end{array}$ & $\underset{\text { Deriod }}{\text { 2nd }}$ & $\begin{array}{l}\text { Number } \\
\text { days }\end{array}$ & & & $\begin{array}{l}\text { With } \\
\text { oral }\end{array}$ & $\underset{\text { days }}{\text { Number }}$ & $\begin{array}{c}\text { Without } \\
\text { oral }\end{array}$ & $\begin{array}{c}\text { Number } \\
\text { days }\end{array}$ & & \\
\hline 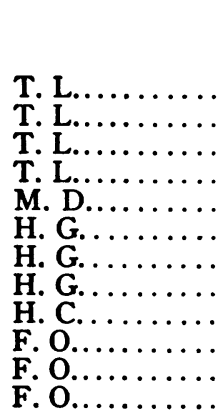 & $\begin{array}{l}15.15 \\
28.1 \\
23.7 \\
24.2 \\
11.0 \\
20.0 \\
23.5 \\
31.6 \\
5.6 \\
21.7\end{array}$ & $\begin{array}{l}\mathbf{6} \\
5 \\
6 \\
5 \\
4 \\
3 \\
\\
2 \\
3 \\
4 \\
3\end{array}$ & $\begin{array}{r}18.4 \\
105.7 \\
14.9 \\
5.7 \\
45.1 \\
16.9 \\
\\
15.3 \\
77.0 \\
12.9 \\
45.3\end{array}$ & $\begin{array}{l}\mathbf{4} \\
\mathbf{3} \\
\mathbf{5} \\
\mathbf{5} \\
\mathbf{4} \\
\mathbf{3} \\
\\
\mathbf{4} \\
\mathbf{3} \\
\mathbf{4} \\
\mathbf{2}\end{array}$ & 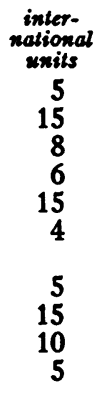 & 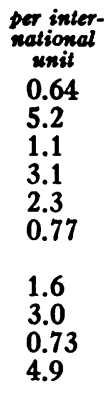 & $\begin{aligned} 17.6 \\
45.7 \\
18.0 \\
13.3 \\
37.4 \\
13.9 \\
7.5 \\
7.7 \\
120.3 \\
13.7 \\
5.7 \\
32.6\end{aligned}$ & $\begin{array}{r}4 \\
3 \\
9 \\
9 \\
2 \\
11 \\
6 \\
5 \\
2 \\
5 \\
4 \\
11\end{array}$ & $\begin{array}{r}28.1 \\
105.7 \\
20.4 \\
24.2 \\
45.1 \\
21.5 \\
25.1 \\
22.6 \\
101.1 \\
24.6 \\
15.9 \\
55.4\end{array}$ & $\begin{array}{l}5 \\
3 \\
6 \\
5 \\
4 \\
5 \\
5 \\
5 \\
2 \\
5 \\
6 \\
3\end{array}$ & $\begin{array}{r}10.5 \\
60.2 \\
2.4 \\
10.9 \\
7.7 \\
7.6 \\
17.6 \\
14.9 \\
19.2 \\
10.9 \\
10.2 \\
22.8\end{array}$ & $\begin{array}{r}16.0 \\
12.0 \\
2.5 \\
3.2 \\
3.4 \\
10.0 \\
22.0 \\
9.0 \\
6.4 \ddagger \\
15.0 \\
2.1 \\
4.6\end{array}$ \\
\hline
\end{tabular}

* Difference in 1st two urine sugars divided by units in Column $A$.

$\dagger$ Column $C$ divided by Column B.

‡ Protamine insulin used; unitage equivalent confirmed by difference in fasting blood sugar.

\section{Unitage effect of oral insulin}

Table III shows a number of estimations of the effect of oral insulin in terms of subcutaneous insulin. This was accomplished in the following manner: From a change in subcutaneous insulin alone, wherever adjacent periods could be obtained for the purpose, the difference was found in the urine sugar at the higher and the lower levels of subcutaneous insulin. This difference in grams was then divided by the number of units by which the two periods differed; for example, with subject T. L. a change in subcutaneous insulin amounting to 5 units occurred between two adjacent periods, one represented by six days, the other by four. This difference amounted to 3.25 grams. This figure divided by 5 gives the value under Column $\mathrm{B}$, namely 0.64 gram reduction per I. U. of subcutaneous insulin. This test was immediately followed by a test with oral insulin in which there was a change due to the oral insulin of 10.5 grams. It is therefore reasonable to infer that the dose of oral insulin had a proportionate effect on urine sugar. This is found by dividing 10.5 grams by 0.64 , which gives an equivalent of 16 subcutaneous units.

All of the other tests are calculated in the same manner, and it will be observed that the largest effect in terms of subcutaneous insulin was obtained with patient $H$. G., who in a period of six days on oral insulin showed a reduction in urine sugar amounting to 17.6 grams. In a previous test, from a change in subcutaneous insulin amounting to 4 units there was a reduction in urine of 0.77 grams per unit. Dividing 17.6 grams' reduction by 0.77 , we get the effect produced by oral insulin. If this degree of effect could be regularly obtained with diabetic patients, the oral method would be of considerable significance, especially in mild cases.

It was hoped that the fasting blood sugar change might also be made the basis of calculation of unitage effects, but this proved to be disappointing on account of the great variability in the behavior of the fasting blood sugar. In one case, patient $\mathrm{H}$. C., who was getting protamine insulin, it was possible to calculate a unitage effect from the change in fasting blood sugar, both from a change of subcutaneous insulin and from the change produced by oral insulin. The figures calculated from urine sugar change and fasting blood sugar change agreed very well.

The range of unitage effect with any single patient was disappointingly large; for example, with subject T. L. in the later periods of study the unitage effect was only in the neighborhood of 2 to 3 units, whereas at the beginning of the study with him the equivalent effect was, in two periods, 16 and 12 units, respectively. Also with subject 
TABLE IV

Evidence of increased combustion of glucose from respiratory metabolism of $F$. $O$.

\begin{tabular}{|c|c|c|c|c|c|c|c|}
\hline Date & & $\begin{array}{c}\text { L. CO, } \\
\text { per } \\
\text { hour }\end{array}$ & $\begin{array}{c}\text { L. Oz } \\
\text { per } \\
\text { hour }\end{array}$ & $\begin{array}{l}\text { Respira- } \\
\text { tory } \\
\text { quotient }\end{array}$ & $\begin{array}{l}\text { Calories } \\
\text { per } \\
\text { hour }\end{array}$ & $\begin{array}{l}\text { Calories } \\
\text { from carbo- } \\
\text { hydrates }\end{array}$ & $\begin{array}{l}\text { Extra glu- } \\
\text { cose burned } \\
\text { per hour }\end{array}$ \\
\hline 1939 & & & & & & & grams \\
\hline February 28 & $\begin{array}{c}\text { Basal } \\
\text { After } 200 \text { international units } \\
\text { oral insulin }\end{array}$ & $\begin{array}{r}9.41 \\
11.57\end{array}$ & $\begin{array}{r}9.99 \\
10.25\end{array}$ & $\begin{array}{l}0.94 \\
1.13\end{array}$ & $\begin{array}{l}49.7 \\
53.16\end{array}$ & $\begin{array}{l}40.17 \\
51.73\end{array}$ & 3.06 \\
\hline March & $\begin{array}{l}\text { Basal } \\
\text { After } 400 \text { international units } \\
\text { oral insulin }\end{array}$ & $\begin{array}{r}8.92 \\
11.11\end{array}$ & $\begin{array}{l}10.27 \\
10.51\end{array}$ & $\begin{array}{l}0.87 \\
1.06\end{array}$ & $\begin{array}{r}50.19 \\
53.69\end{array}$ & $\begin{array}{l}28.85 \\
53.04\end{array}$ & 6.39 \\
\hline
\end{tabular}

F. O. the unitage effect ranged from 2 to 15 units of subcutaneous insulin.

\section{Evidence of increased combustion}

On several occasions basal metabolisms were determined on four different patients in the group of twelve listed in Table II. With only one of these, however, was there definite evidence of increased combustion after a dose of oral insulin. Two tests on this patient, F. O., are given in Table IV. The experiments on February 28 and March 2 were performed in identical manner, except that in the second test twice as much oral insulin was given as in the first. A basal period was obtained early in the morning before breakfast, and immediately thereafter the dose of insulin was given. One hour later another respiratory metabolism period was run exactly in the same manner as the basal. The results show in these two tests a nearly proportional effect as between 200 and 400 units of insulin administered orally. For the purpose of such respiratory metabolism experiments the usual carbonate mixture was replaced with a Sörensen phosphate buffering solution, giving a $\mathrm{pH}$ of 10 . With the carbonate mixture there might be a chance that increased carbon dioxide in the expired air had come from the carbonate mixture. The phosphate buffering solution with this particular patient favored the absorption of insulin quite as well as did the carbonate buffer of the same $\mathrm{pH}$. It is interesting also to note that in this particular patient, F. O., the phosphate buffering solution raised the carbon dioxide combining power of the blood. Consequently, the actual effect of the oral insulin on combustion was somewhat greater than indicated in the last column. Observe that the principal effect, notwithstanding increased combining power, was upon the $\mathrm{CO}_{2}$ expired rather than on the $\mathrm{O}_{2}$ inspired, and that respiratory quotients higher than 1.0 were obtained. They are not non-protein respiratory quotients, however, and therefore no inference can be drawn regarding fat formation.

It is surmised that, in the several tests on other subjects which showed a good drop in blood sugar but failed to show increased combustion, there actually was some increase but that it was masked by the increased alkalinity of the blood holding back carbon dioxide produced from the extra combustion. Another possibility is that the reduction of blood sugar was caused entirely by increased glycogen formation.

\section{DISCUSSION}

The only clinical work with which this investigation can be compared is that of Lasch and Schönbrünner (9). These authors found in previous experiments $(10,11)$ that acidic dye stuffs such as Congo red and trypan red would completely protect insulin from the destructive effects of pepsin, and that basic dyes such as malachite green and rhodamine would protect it equally against digestive destruction by trypsin. Accordingly, for their human experiments they combined these protective agents with dry insulin in a lacquer-covered tablet. Saponin also (Merck and Company) was included as a surface-tension lowering agent designed to promote absorption. Since experiments on normal human subjects had proved that none of the adjuvant substances was harmful and that blood-sugar lowering could be obtained, the authors proceeded to treat human cases of diabetes in several clinics with such tablets (composition not stated). "Only station- 
ary cases were selected, the status of whose metabolism had been established regularly over a sufficiently long fore-period, and with whom a post-experimental observation period appeared to be possible." Results were in hand on more than forty cases at the time the clinical report was written. Only eight, however, are represented in the graphs, and no tables are presented.

Marked reduction of (fasting?) blood sugar and reduction of urine sugar to the vanishing point or maintenance at low levels by means of oral insulin, are illustrated in all of the eight cases. The authors rely upon increases of body weight as proof of the non-interference with digestion and absorption of food by the protecting dyestuffs. This at best is hazardous and in the present instance proves quite inconsistent with the dietary record. For example, in one case (Number 5) the " standard diet" is described as " 200 grams meat, 50 grams butter, 2 eggs," and contains 50 grams of carbohydrate. From these articles alone the patient weighing $63 \mathrm{kgm}$. received only 910 calories, and during the first three days of the chart (without insulin) lost an average of 70 grams of glucose in the urine, or approximately 266 calories. Yet during this period she gained in weight! During the next six days with subcutaneous insulin the urine became sugar-free, but the weight did not change!

Another case (Number 3), weighing $61 \mathrm{kgm}$., on a standard diet " with 200 grams meat, 50 grams fat and 50 grams carbohydrate" during the first ten days of the chart (without insulin) excreted an average of 73.5 grams of glucose but had no acetonuria, and the weight ended where it started. The diet described would supply only 845 calories, of which 278 calories were lost in the urine daily.

It would seem that the favorable changes in weight with oral insulin must have been caused by constituents of the diet not described. How can the authors convince themselves from such data that digestion was not interfered with, or the reader be assured that a great deal of the reduction in urine sugar was not due to partial fasting caused by such interference? No examination of the stools seems to have been made.

If trypan red and malachite green protect insulin from digestion in the alimentary tract, why do they not also protect other proteins from di- gestion, especially as the tablets were given after breakfast and one hour before the mid-day and evening meals and never on a completely empty stomach?

From unpublished experiments in this laboratory with trypan red administered to dogs with insulin and hexylresorcinol, no additional effect has ever been obtained. Furthermore, after several doses of trypan red the dogs exhibited redstaining of the sclera of the eyes, skin and toenails, and they did not become entirely free from this coloration for a month or more.

The authors' experience with saponin as a promoter of absorption is completely at variance with that of Samek (12), Dingemanse and Lacqueur (13), Walton and Bassett (14), and with this laboratory (15). In our experience saponin placed directly in the intestine of an anesthetized dog with insulin interferes with absorption more often than it aids it, as judged by the effect on blood sugar. For example, in a recent series of twelve experiments, only one seemed decidedly to enhance absorption, two were doubtful, i.e. just on the edge of significance, and nine indicated definite interference with absorption. Lasch and Schönbrünner state that their tablets without saponin had no effect at all.

Not all of their cases (percentage not given) gave a therapeutically recognizable effect and apparently the authors attribute this failure to an insufficient dosage of saponin to produce absorption. Those who did respond favorably gave unmistakable lowering of blood sugar and urine sugar and favorable effects on body weight as well as general clinical condition.

The results obtained from the present investigation parallel those of Lasch and Schönbrünner, except for the magnitude of the effects, judging by the few which they disclose. In our study, however, we are certain that there was no interference with digestion sufficient to cause loss of nutrients by the stools. Since this work started, it has been shown in our laboratory ${ }^{2}$ that hexylresorcinol does interfere with the proteolytic action of pepsin, trypsin and erepsin, but the effect in vivo must be quite fleeting so far as digestion of food proteins is concerned. We have pur-

2 These results were obtained by Mr. R. L. Driver and will be published later. 
posely limited the use of adjuvant substances to the point where the over-all digestion in twentyfour hours was demonstrably normal.

\section{SUMMARY}

1. Twenty cases of human diabetes of varying degrees of severity have been employed in this study of the effects of hexylresorcinol and a buffering mixture of salts on the absorption of insulin from the alimentary tract.

2. The "standard dose" was $100 \mathrm{I}$. U. pure insulin in a solution containing 0.125 per cent hexylresorcinol and alkaline salts necessary to give a $\mathrm{pH}$ of approximately 10 to $\mathbf{1 0 . 5}$.

3. As many as eight such standard doses can be given in one day without interference with total digestion, the last dose being administered not later than 11 p.m. and the twenty-four-hour urine period closing at 7 a.m. Diets were kept constant for control and experimental periods.

4. Detailed results on urine sugar for twentyfour hours, and blood sugar change early in the morning from the first dose of oral insulin, are presented for the twelve cases who reacted most favorably. These show weighted average effects on urine sugar varying from 4.7 grams to 17.7 grams per twenty-four hours below the average excretion in control periods. The blood sugar effect from the single dose, again as a weighted average, varied from nothing (Case $H$. C.) to 60 mgm. per cent in forty-five minutes (F. O). The total insulin per twenty-four hours varied from 200 or $300 \mathrm{I}$. U. to $800 \mathrm{I}$. U. The effects on urine sugar were not proportional to dosage, often being as great with 200 to $300 \mathrm{I}$. U. as with 600 to 800 I. U. Greater effects were obtained when urine sugar and fasting blood sugar were high than when they were low.

5. The equivalent unitage effects of oral insulin in terms of subcutaneous (regular) insulin varied from $2.1 \mathrm{I}$. U. to $22 \mathrm{I}$. U., the average of five cases in which this assay was possible being for all doses of oral insulin just under $10 \mathrm{I}$. U. of subcutaneous insulin.

6. In a single case it was possible to make out an effect nearly proportional to a dose of oral insulin, and in this case also to demonstrate an effect on respiratory metabolism which could be calculated in terms of glucose oxidized.
7. These results are only mildly encouraging to the hope of adequate control of diabetes mellitus with oral insulin.

\section{CASE ABSTRACTS}

T. L. A 23-year-old white male found to have diabetes mellitus in 1930. Diet at home previous to admission: calories, 2083; protein, 78; fat, 101 ; carbohydrate, 201 ; with insulin s.c. 30-20-28. Admitted for metabolic study December 26, 1937. Placed on diet as follows: calories, 2075 ; protein, 80 ; fat, 100 ; carbohydrate, 200 . Continued on this diet through the administration of oral insulin. Subcutaneous insulin before oral started, 25-55-10. On February 6 diet was increased to: calories, 2558; protein, 80 ; fat, 123 ; carbohydrate, 265 . Continued on this diet as oral was again started March 2, 1938. Subcutaneous insulin before oral, 14-12-12-10. Discharged and returned May 27, 1938 to re-enter diabetic study. Diet as follows: calories, 2558; protein, 80 ; fat, 123; carbohydrate, 265. Continued on this diet through oral administration. Subcutaneous insulin before oral, 30-0-12-6.

$M$. D. A 20-year-old white male. Known diabetic since 1931. Insulin at home just previous to admission December 27, 1937 not recorded. Last record of insulin taken at home that is stated in history was October 30 , 1936, when patient was discharged from hospital on 3500 calories with protamine insulin 30 units and regular insulin 25 units a.c. breakfast. Admitted for diabetic study December 27, 1937. Placed on following diet: calories, 1850 ; protein, 65 ; fat, 90 ; carbohydrate, 182 . Continued on this diet, although there were several slight changes due to addition of orange juice for insulin reaction. Subcutaneous insulin before oral started, 20-5-5-10.

$H$. G. This 42-year-old white male had first symptoms of diabetes in 1928 at the age of 32 years. Diet at home previous to admission : calories, 1646; protein, 70; fat, 80; carbohydrate, 150; with insulin s.c. 35-10-35. Admitted for metabolic study February 16, 1938. Placed on following diet: calories, 2150 ; protein, 76; fat, 105; carbohydrate, 210. Continued on this diet until administration of oral insulin. Subcutaneous insulin before oral stated, 12-10-12-10. Discharged April 3, 1938 to return in one week or ten days. Re-admitted for diabetic study April 19, 1938. Placed on same diet as in previous study; calories, 2150; protein, 76; fat, 105; carbohydrate, 210 . Continued on this diet through oral administration. Subcutaneous insulin before oral started, 15-10-12-10.

$J . H$. A 21-year-old white male who was first found to be a diabetic at the age of 10 years. Diet at home previous to admission: calories, 2060; protein, 80; fat, 100; carbohydrate, 196; with insulin s.c. 40-0-30. Admitted for diabetic study February 16, 1938. Placed on following diet: calories, 2050; protein, 75; fat, 100; carbohydrate, 198. Continued on this diet with the administration of oral insulin. Subcutaneous insulin before oral started, 14-12-10-6.

H. C. A 17-year-old white male first showed symp- 
toms of diabetes in 1936. Diet at home previous to admission: calories, 2570; protein, 107; fat, 116; carbohydrate, 257 ; with protamine insulin 40 units a.c. breakfast and regular insulin 20 units a.c. supper. Admitted for diabetic study April 19, 1938. Placed on diet as follows : calories, 2570; protein, 107; fat, 125 ; carbohydrate, 236. Continued on this diet through the administration of oral insulin. Subcutaneous insulin before oral started, protamine 15 units, regular 10 units.

L. $P$. A 23-year-old white male. First knowledge of diabetes in 1936. Diet at home previous to admission: calories, 2450; protein, 133 ; fat, 92 ; carbohydrate, 257 ; with insulin s.c., protamine insulin 50 units, regular insulin 10 units in the a.m. Admitted for metabolic study June 4, 1938. Placed on the following diet: calories, 2460; protein, 90 ; fat, 120 ; carbohydrate, 238 . Continued on this diet through the administration of oral insulin. Subcutaneous insulin before oral started, 10-0-5-0.

$T$. $V$. A 16-year-old Italian boy first showed symptoms of diabetes at the age of 12 . Diet at home: calories, 2125 ; protein, 82 ; fat, 122 ; carbohydrate, 184 ; with protamine insulin 35 units, and regular insulin 15-0-20. Admitted for diabetic study April 19, 1938. Placed on diet : calories, 2020; protein, 82 ; fat, 100 ; carbohydrate, 184. Continued on this diet with administration of oral insulin. Subcutaneous insulin before oral started, protamine 15 units, regular 10 units; later changed to protamine 15 units, regular 25 units.

F. O. A 34-year-old white male with diabetes of one year's duration. Diet at home (a gap of eight months in history) not recorded. Admitted for diabetic study January 4, 1939. Placed on the following diet: calories, 1907 ; protein, 78 ; fat, 94 ; carbohydrate, 174 . Final constant diet : calories, 1980; protein, 78 ; fat, 107 ; carbohydrate, 177. Subcutaneous insulin before oral started, 10-0-0-0.

$P$. F. A 56-year-old white male who has been a known diabetic since 1930-1931. Diet at home before admission 1800 calories. Insulin taken at home 25-0-15. Admitted for special study December 27, 1938. Placed on the following diet: calories, 1760 ; protein, 68 ; fat, 100 ; carbohydrate, 147. Final constant diet before oral administration: calories, 1764 ; protein, 69 ; fat, 100 ; carbohydrate, 147. Subcutaneous insulin before oral, 30-0-15-0.

$P$. J. A 57-year-old white woman, a known diabetic for ten years. Diet at home 1600 calories. Protamine insulin daily at home, 25 units. Admitted for study June 6, 1939. Placed on the following diet: calories, 1646; protein, 62 ; fat, 80 ; carbohydrate, 158 . Continued on this diet through diabetic study. Subcutaneous insulin before oral started, 10-0-0.

E. $W$. A 32-year-old Negress, a known diabetic for nine years. Protamine insulin (taken at home) 30 units, regular insulin 10 units, a.c. breakfast daily. Admitted for diabetic study June 6, 1939. Placed on following diet : calories, 1230 ; protein, 60 ; fat, 70 ; carbohydrate, 135. Continued on this diet through study. Subcutaneous insulin before oral started, 25-10-10.

$W . V$. A 47-year-old minister who apparently had had diabetes for about nine years. Diabetes first discovered three years ago. Regular insulin, 25 units daily, at home. (History does not state when this was taken.) Admitted for study June 23, 1939. Placed on following diet : calories, 2120 ; protein, 70 ; fat, 105 ; carbohydrate, 210 . Continued on this diet through diabetic study. Subcutaneous insulin before oral started, 25-0-0.

\section{BIBLIOGRAPHY}

1. Murlin, J. R., Tamboulian, R. L., and Pierce, H. B., Absorption of insulin from Thiry-Vella loops of the intestine in normal and depancreatized dogs. Am. J. Physiol., 1937, 120, 733.

2. Daggs, R. G., Murlin, W. R., and Murlin, J. R., The effect of hexylresorcinol upon the absorption of insulin from the gastro-intestinal tract of dogs. Am. J. Physiol., 1937, 120, 744.

3. Young, L. E., Phillips, W. A., and Murlin, J. R., New results on the absorption of insulin from the alimentary tract. Am. J. Physiol., 1939, 128, 81.

4. Sealock, R. R., Murlin, J. R., and Driver, R. L., A comparative study of the effect of alkylresorcinols and related compounds upon the absorption of insulin from isolated intestinal loops of anesthetized dogs. Am. J. Physiol., 1939, 128, 92.

5. Murlin, J. R., Young, L. E., and Phillips, W. A., New results on the absorption of insulin from the alimentary tract. Science, 1937, 86, 412.

6. Shaffer, P. A., and Somogyi, M., Copper-iodometric reagents for sugar determination. J. Biol. Chem., 1933, 100, 695.

7. West, E. S., Scharles, F. H., and Peterson, V. L., The determination of true sugar of blood. J. Biol. Chem., 1929, 82, 137.

8. Somogyi, M., A method for the preparation of blood filtrates for the determination of sugar. J. Biol. Chem., 1930, 86, 655.

9. Lasch, F., and Schönbrünner, E., Experimentelle Untersuchungen über perorale Insulintherapie unter Beigabe organischer Farbstoffe. Klin. Wchnschr., 1938, 17, 1177.

10. Idem, Utber die Erhaltung der Insulinwirkung in Verdauungssäften durch Beigabe organischer Farbstoffe. Klin. Wchnschr., 1938, 17, 114.

11. Idem, Weitere Untersuchungen über die enterale Insulinresorption. Utber den Schutz des Insulins gegen Trypsin. Arch. f. Exper. Path. u. Pharmakol., 1936, 182, 452.

12. Samek, G., Zur Frage der peroralen Insulinzufuhr. Ztschr. f. d. ges. Exper. Med., 1928, 62, 707.

13. Dingemanse, E., and Laqueur, E., Über die angebliche Wirkung des Insulins bei der Darreichung per os in Gegenwart von Saponin. Arch. f. Exper. Path. u. Pharmakol., 1928, 126, 31.

14. Walton, R. P., and Bassett, E. F., Enteral absorption of insulin. Proc. Soc. Exper. Biol. and Med., 1933, 30, 1184.

15. Driver, R. L., and Murlin, J. R. (Unpublished data.) 